\title{
“Guiding Block Performance” sebagai Solusi Untuk Mengekspresikan Tarian Pakkarena Bagi Perempuan Penyandang Tunanetra di Makassar Sulawesi Selatan
}

\author{
Ashabul Kahfi ${ }^{1 *}$, Andi Taslim Saputra ${ }^{1}$, Rahmawati Addas $^{2}$, Andi Afif Rofii ${ }^{3}$ \\ ${ }^{\mathbf{1} P r o d i}$ Teater, Fakultas Seni Pertunjukan Institut Seni Indonesia Surakarta \\ ${ }^{2}$ Prodi Televisi dan Film, Fakultas Seni Rupa dan Desain Institut Seni Indonesia Surakarta \\ ${ }^{3}$ Prodi Desain Interior, Fakultas Seni Rupa dan Desain Institut Seni Indonesia Surakarta \\ *Penulis Korespondensi, Ashabul Kahfi Prodi Teater FSP Institut Seni Indonesia Surakarta \\ Email: taslimsaputra31@gmail.com
}

\begin{abstract}
ABSTRAK
Salah satu hal yang cukup ironi adalah terbatasnya ruang gerak bagi penyandang tunanetra, terutama dalam konteks pendidikan, sarana, lahan kerja, dan wadah berkesenian. Cara dunia bekerja pada hari ini begitu mengabaikan orang-orang yang menyandang tunanetra, yang sebenarnya penyandang tunanetra sangat sulit untuk menghadirkan alat-alat yang mendukung aktivitasnya. Sebagaimana yang diajukan alat oleh kelompok ini memilih aktivitas kesenian yang menjadi salah satu sandaran agar tetap mampu merayakan keinginan mengekspresikan diri penyandang tunanetra. Produk Guiding Block Performance yang bisa menjadi penunjuk arah di atas panggung pertunjukan dan mempunyai nilai fungsi yang lebih dibanding lantai panggung pertunjukan saat ini yang diperuntukkan untuk penyandang tunanetra. Sehingga Guiding Block Performance ini bermanfaat khususnya bagi penyandang tunanetra yang selama ini tidak mendapatkan perhatian khusus dalam mengekspresikan jiwa seninya dalam konteks seni pertunjukan, khususnya tari. Hasil yang dicapai pada pelaksanaan ini menciptakan sebuah desain baru Guiding Block yang diperuntukkan khusus untuk penyandang tunanetra. Adapun desain guiding itu terdiri dari dua bentuk, yakni desain guiding block dengan enam tanda panduan dan desain pola lantai untuk Guiding Block Performance. Dengan kehadiran alat ini maka menjadi alat advokasi yang terhubung ke pemerintah untuk kembali memperhatikan fungsi dan posisi Guiding Block yang bermanfaat bagi kehidupan penyandang tunanetra. Upaya-upaya menciptakan ruang publik yang ramah bagi penyandang tunanetra dengan inisiatif aksi berkesenian. Sebab tubuh manusia membutuhkan asupan nilai estetis. Ekspresi tari yang menghadirkan kepekaan spiritual dan estetis juga patut diperjuangkan untuk penyandang tunanetra.
\end{abstract}

Kata Kunci: Guiding Block Performance, Tari Pakkarena, Penyandang Tunanetra.

\section{ABSTRACT}

One of the things that is quite ironic is the limited space for blind people, especially in the context of education, facilities, work space, and art platforms. The way the world works today is so ignoring blind people, actually blind people find it very difficult to provide the tools that support their activities. As suggested by the tool, this group chooses artistic activities to support in order to be able to celebrate the desire to express themselves with visual impairments. Guiding Block Performance products that can be a direction on the stage of the show and have more functional value than the current performance stage floor which is intended for blind people. So that Guiding Block Performance is especially beneficial for blind people who have not received special attention in expressing their artistic soul in the context of performing arts, especially dance. The results achieved in this implementation created a new Guiding Block design specifically for blind people. The guiding design consists of two forms, namely the guiding block design with six guide signs and the floor pattern design for Guiding Block Performance. With the presence of this tool, it becomes an advocacy tool that is connected to the government to return to attention to the functions and positions of the Guiding Block which are beneficial for the lives of blind people. Efforts to create friendly public spaces for blind people through artistic action initiatives. Because the human body needs aesthetic value intake. Dance expressions that convey spiritual and aesthetic sensitivity should also be fought for for blind people.

Keywords: Guiding Block Performance, Pakkarena Dance, Blind People. 


\section{PENDAHULUAN}

Kesenian adalah investasi yang diharapkan hadir untuk membangun kebudayaan. Bahkan kesenian menjadi sesuatu yang disoroti oleh pemerintah dalam membangun kebudayaan. Bagaimana tidak, kesenian menjadi instrument yang mendukung terciptanya pemajuan kebudayaan. Hal itu juga dicanangkan dalam RUU kebudayaan yang disahkan pada tanggal 24 Mei 2017 oleh presiden Jokowi, di mana seni dan budaya menjadi objek yang vital dalam pemajuan kebudayaan. Dalam bunyi Undang-Undang Republik Indonesia nomor 5 tahun 2017 tentang pemajuan kebudayaan "Bahwa Negara memajukan Kebudayaan Nasional Indonesia di tengah peradaban dunia dan menjadikan Kebudayaan sebagai investasi untuk membangun masa depan dan peradaban bangsa demi terwujudnya tujuan nasional sebagaimana diamanatkan oleh Undang-Undang Dasar Negara Republik Indonesia Tahun 1945" (Undang-Undang Republik Indonesia nomor 5 tahun 2017).

Dalam konteks ini, setiap masyarakat Indonesia diharapkan oleh Negara untuk bersama-sama membangun kebudayaan. Artinya, pemajuan kebudayaan berlaku secara universal bagi setiap masyarakat Indonesia, termasuk penyandang difabel (Tunanetra) sebagai subyek yang diharapkan memberikan sumbangsih dalam pemajuan kebudayaan. Penyandang difabel terutama tunanetra memiliki hak untuk mengekspresikan diri dalam konteks seni pertunjukan.

Di Indonesia, penyandang disabilitas diperkirakan mencapai 36. 150. 000 orang atau sekitar $15 \%$ dari total penduduk Indonesia tahun 2011 yang penduduknya mencapai 241 juta jiwa sebagian besar adalah penyandang tunanetra (Syafi'ie, 2014). Berdasarkan KBBI, tunanetra adalah seseorang yang mengalami gangguan dalam penglihatannya. Atas dasar hal itu maka penyandang tunanetra mengalami kesulitan apabila ingin menunjukkan kebolehan dalam wilayah kesenian, khususnya seni tari. Untuk menyiasati kondisi yang dialami oleh penyandang tunanetra, maka kita perlu melakukan suatu langkah terobosan untuk mengatasi kondisi tersebut. Sebagai contoh pada ruang pertunjukan yang ada sekarang kebanyakan ruang pertunjukan tidak memiliki lantai yang ramah bagi penyandang tunanetra. Maka dengan ruang pertunjukan yang umum, apabila penyandang tunanetra melakukan pertunjukan tari tentu tidak akan mungkin, karena terjadi disorientasi posisi.

Dalam praktik kesenian, kegiatan pelatihan kesenian dilakukan hampir oleh semua orang atau semua kalangan. Bagi pelaku kesenian ketika melakukan latihan atau melaksanakan pentas harus dilakukan di ruang pertunjukan. Namun demikian, penyandang tunanetra tidak memiliki keberanian untuk melakukan pentas, karena adanya kelemahan indra dan juga tidak didukung fasilitas yang aksesibilitas di ruang pertunjukan. Atas dasar hal itu, bagi penyandang tunanetra untuk melakukan kegiatan pentas tentunya diperlukan suatu alat atau sarana yang bisa digunakan sebagai penunjuk arah karena fasilitas panggung pertunjukan yang ada saat ini tidak mewadahi keinginan mereka dalam berekspresi yang perlu ada solusinya.

Dan pernyataan-pernyataan di atas merupakan kegelisahan-kegelisahan yang disampaikan oleh penyandang tunanetra, di mana mereka ingin mengekspresikan diri lewat kesenian sedangkan tempat atau ruangan yang tersedia tidak ada satupun yang ramah ataupun representatif bagi penyandang tunanetra. Berdasarkan pada hal tersebut di atas maka kami terinspirasi untuk membuat Guiding Block dengan mengimplementasikan gerak tari Pakkarena. Tari Pakkarena adalah 
tari ciptaan Anida yang pada awalnya merupakan wujud tarian pemujaan yang bernama Sere Jaga. Sere bermaksud mundarmandir atau ke sana ke mari, manakala Jaga bermaksud berjaga dan tidak tidur semalam suntuk yang menghibur audience (Anonim, 2020). Tarian ini tidak hanya ditarikan oleh perempuan tetapi juga ditarikan laki-laki. Tarian Pakkarena dijadikan rujukan untuk membuat pola gerak pada Guiding Block Performance. Pemilihan tarian Pakkarena yang diimplementasikan di Guiding Block Performance dalam rangka pemajuan kebudayaan dan juga disesuaikan dengan lokasi domisili dari tim Program Kreativitas Mahasiswa ini. Sebenarnya, Guiding Block Performance ini dapat diterapkan di setiap wilayah disesuaikan dengan adat dan budaya yang ada.

Ragam gerak tarian Pakkarena kemudian dialihkan ke ubin yang di sebut Guiding Block Performance yang disimpan pada lantai ruang pertunjukan tanpa mengurangi nilai fungsi dan juga bentuk representatifnya, sehingga mampu mewadahi keinginan berekspresi dan meningkatkan kepercayaan diri bagi penyandang tunanetra pada waktu pertunjukan, dan pemikiran tersebut kami tuangkan dalam pembuatan lantai yang kami beri nama "Guiding Block Performance".

\section{Tujuan dan Manfaat Kegiatan}

Produk yang akan kami rancang kami beri nama Guiding Block Performance adalah produk yang berupa Guiding Block yang terbuat dari bahan batu bata. Guiding Block Performance tersebut adalah original produk baru berasal dari hasil pemikiran kami, karena produk ini belum pernah diperuntukkan untuk ruang pertunjukan dan belum diproduksi secara luas. Produk ini mempunyai keunggulan dari sisi manfaat bagi penyandang tunanetra, adapun untuk penjelasannya sebagai berikut. a. Sangat cocok ditempatkan pada ruangan pertunjukan, karena Guiding Block Perfomance bisa dilipat bila tidak dipergunakan.

b. Guiding Block Perfomance bisa berfungsi sebagai penunjuk arah dan laku bagi penyandang tunanetra selama pertunjukan.

c. Pada waktu pertunjukan, Guiding Block Perfomance bisa berfungsi sebagai perangsang kepercayaan diri bagi penyandang tunanetra.

d. Dengan adanya alat Guiding Block Performance, maka ruang pertunjukan menjadi ramah dan representatif bagi penyandang tunanetra.

e. Guiding Block Perfomance diproduksi untuk menunjang aksesbilitas bagi penyandang tunanetra di lingkup pertunjukan seni.

\section{METODE PELAKSANAAN}

\section{Sasaran kegiatan}

Sasaran pelaksanaan kegiatan pelatihan ini adalah penyandang tunanetra yang berjenis kelamin perempuan dan juga anak-anak yang berumur 10-15 tahun.

\section{Metode yang digunakan :}

Tahapan-tahapan yang kita lakukan untuk melaksanakan kegiatan PKM ini melalui beberapa tahapan, diantaranya:

1. Tahap ini diawali dengan melakukan observasi dan pengenalan tentang panggung dan lantai secara bertahap dan melihat Guiding Block di ruang publik sebagai referensi.

2. Tahap berikutnya, mengumpulkan data dengan menggunakan metode survei, proses ini dilakukan dengan melihat langsung hasil dan survei.

3. Setelah melalui proses sebelumnya, tentu selanjutnya adalah menganalisa hasil survei untuk mengidentifikasi masalah yang perlu diteliti untuk menentukan alat dan icon-icon untuk diterapkan dilantai 
Guiding Block Performance yang tepat sesuai kebutuhan penyandang tunanetra.

4. Tahap selanjutnya yaitu perancangan peralatan dan persiapan komponen yang digunakan.

5. Tahap selanjutnya yaitu perakitan instrument model ubin Guiding Block Performance dan pola lantai.

6. Tahap terakhir adalah melakukan evaluasi kritis sejauh mana alat ini berdampak bagi penyandang tunanetra.

\section{HASIL DAN PEMBAHASAN}

Guiding Block di ruang publik dapat kita pahami sebagai penuntun arah bagi penyandang tunanetra. Seperti kita ketahui fasilitas yang berada di ruang publik belum sepenuhnya mewadahi dan kurangnya aksesibilitas untuk penyandang tunanetra. Bahkan kebanyakan pemasangan Guiding Block di ruang publik hanya dilihat dari sisi estetisnya saja tanpa dilihat dari segi fungsionalnya. Sehingga bagi penyandang tunanetra mengalami banyak kendala ketika berjalan di Guiding Block, misalnya di Indonesia Guiding Block dengan jalan zig-zag dan berbagai permasalahnnya. Peranan Guiding Block sangat penting untuk penyandang tunanetra dikarenakan menjadi penuntun jalan. Seolah-olah Guiding Block menjadi mata bagi penyandang tunanetra dan memudahkannya untuk melakukan aktivitas berjalan. Guiding Block pada umumnya terdapat dua tanda pemandu, Di Indonesia tanda tersebut berwarna kuning / berwarna kontras, Guiding Block di pasang di trotoar yang lurus dengan kontur ubin garis empat untuk jalan dan kontur dengan bulatanbulatan kecil pada ubin sebagai penanda stop / warning karena adanya jalur masuknya mobil ke gedung seperti pusat perbelanjaan atau kantor, dan lain-lain (Esdaniar, 2018).

Sampai sejauh ini, panggung masih berbentuk datar sebagaimana yang sering kita saksikan di panggung-panggung yang lain. Keunikan dan beberapa eksplorasi lain belum ada sampai sejauh ini: dengan gagasan Guiding Block yang dialihkan ke panggung. Panggung yang lain biasanya dikerjakan sesuai tema dan karakter yang tentu saja menyesuaikan artistik pertunjukkan. Tetapi Guiding Block kemudian ditujukan ke penyandang tunantera untuk mengekspresikan diri. Tetapi sebelum melihat realitas panggung, tim terlebih dahulu melihat realitas penataan Guiding Block yang diperuntukkan penyandang tunantera di jalanan. Berdasarkan hasil pengamatan melalui data-data internet kami menemukan beragam bentuk penataan Guiding Block di jalalan; kemudian, pengamatan data-data internet kami lanjutkan dalam lingkup ruang-ruang pertunjukan, baik panggung proscenium, panggung arena, dan sebagainya. Kami banyak menemukan panggung yang tidak aksesibilitas, panggung yang tidak mewadahi keinginan berekspresi untuk penyandang tunanetra sebagai berikut.

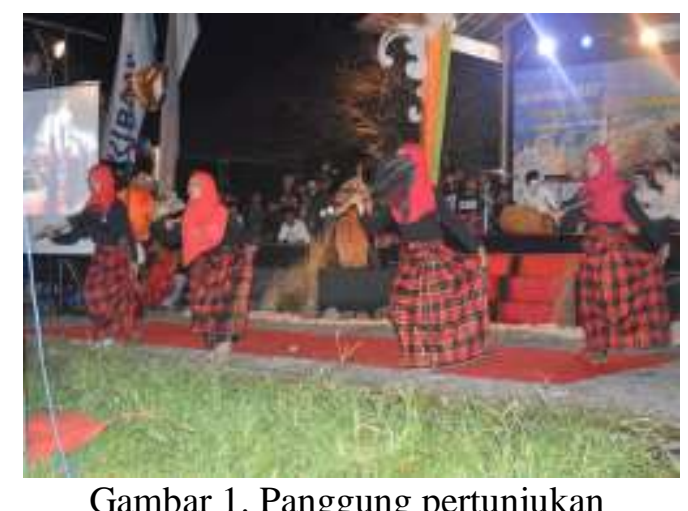

Gambar 1. Panggung pertunjukan

Berdasarkan Permen PU Nomor 30 Tahun 2006 adalah: 1) Tekstur ubin pengarah bermotif garis-garis menunjukkan arah perjalanan. 2) Tekstur ubin peringatan (bulat) memberi peringatan terhadap adanya perubahan situasi di sekitarnya/warning. 3) Daerah-daerah yang harus menggunakan ubin tekstur pemandu (guiding blocks) yaitu: depan jalur lalu-lintas kendaraan, di depan pintu masuk/keluar dari dan ke tangga atau fasilitas persilangan dengan perbedaan ketinggian lantai, di pintu masuk/keluar pada terminal transportasi umum atau area penumpang, pada pedestrian yang 
dalam Guiding Block Performance. Adapun gambar tanda dan model yang tercipta dari gabungan dari metode Guiding Block dan penerapan tanda tari pakkarena menggunakan notasi laban seperti Gambar 2.

Berdasarkan pengamatan langsung sebelum covid-19 melanda dan melalui media daring, menentukan hal yang dibuat selanjutnya yaitu membuat model Guiding Block Performance. Dalam membuat modelmodel ubin yang diimplementasikan ke instrumen Guiding Block Performance kami menggunakan aplikasi blender. Pada proses pembuatan menggunakan aplikasi blender yang biasanya dipakai untuk membuat animasi kami membentuk gambar ubin dengan tektsur yang timbul dan tiga dimensi seperti di bawah ini.

diterapkankembangkan ke gagasan kami. Atas dasar tinjauan di atas, maka Guiding Block Performance adalah sesuatu yang berbeda dari Guiding Block pada umumnya. Dapat di lihat pada Gambar 2.

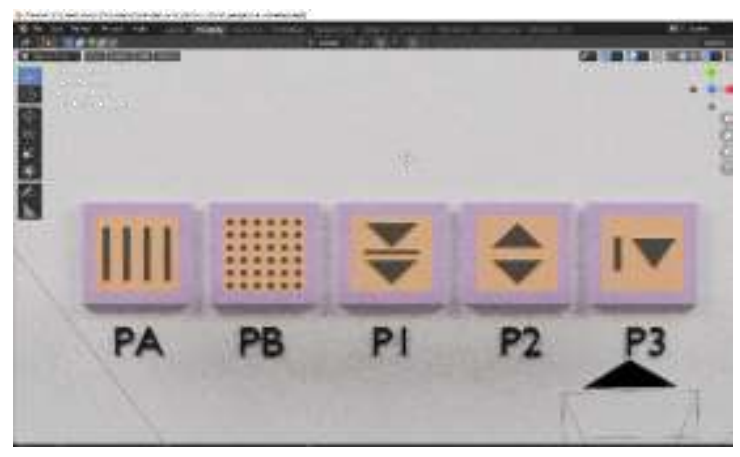

Gambar 2. Pola Lantai Guiding Block Performance tari Pakkarena

Notasi laban adalah suatu sistem yang menganalisa dan merekam pergerakan manusia serta berdasar pada gerakan alami manusia, dan tiap perubahan gerakan harus secara rinci dituliskan notasinya (Pramono, 2008). Notasi laban berupa identifikasi gerakan yang dilakukan oleh penari tanpa mengarahkan gerakan. Dengan bantuan dari pembacaan notasi laban untuk mengetahui gerakan pola lantai, arah, penempatan, pergerakan badan, irama dan pengutaraan dari tari pakkarena, maka kemudian dapat menghasilkan tanda-tanda yang dipakai 
7 Segitiga menghadap ke bawah dan di arsir: Laku berdiri

8 Segitiga dengan garis sebelah kanan: Laku memainkan selendang

Dari hasil desain ubin di atas, maka membuat penyandang tunanetra tidak mengalami kekeliruan saat melakukan perpindahan atau pola gerak. Dukungan dari ubin ini tentunya dibuatkan pola lantai yang dibuat melalui Hal tersebut dilakukan untuk mengantisipasi pemakai Guiding Block Performance tidak saling menumpuk satu sama lain dan pengguna alat ini tidak kebingungan. Kegiatan menari tentunya suatu hal yang rumit makanya untuk memudahkan hal ini diaktualisasikan oleh penyandang tunanetra dihadirkan pola lantai khusus untuk Guiding Block Performance yang di mana pola lantai itu sudah terjelaskan di atas. Pola lantai tersebut di isi oleh ubin-ubin yang di desain oleh kelompok ini.

\section{KESIMPULAN DAN SARAN}

Program ini tentunya mendukung keseteraan setiap umat manusia sehingga menginisiasi produk yang aksesibilitas untuk penyandang tunanetra, khususnya di bidang kesenian dengan menciptakan instrument guiding block untuk menari. Pada pelaksanaan ini menciptakan sebuah desain baru Guiding Block yang diperuntukkan khusus untuk penyandang tunanetra. Adapun desain guiding itu terdiri dari dua bentuk, yakni desain guiding block dengan enam tanda panduan dan desain pola lantai untuk Guiding Block Performance. Dengan kehadiran alat ini maka menjadi alat advokasi yang terhubung ke pemerintah untuk kembali memperhatikan fungsi dan posisi Guiding Block yang bermanfaat bagi kehidupan penyandang tunanetra. Upaya-upaya menciptakan ruang publik yang ramah bagi penyandang tunanetra dengan inisiatif aksi berkesenian. Sebab tubuh manusia membutuhkan asupan nilai estetis. Dari ekspresi tarilah yang menghadirkan kepekaan spiritual dan estetis juga patut diperjuangkan untuk penyandang tunanetra.

\section{UCAPAN TERIMAKASIH}

Terima kasih diucapkan kepada Kementerian Pendidikan dan Kebudayaan (Dikti), Simbelmawa dengan nomor Surat Keputusan 1686/E2/TU/2020 tanggal 5 Agustus 2020, Institut Seni Indonesia Surakarta, Institut Seni dan Budaya Sulawesi Selatan atas bantuan dana dan perlengkapan kegiatan sehingga pelaksanaan kegiatan dapat dengan mudah dan lancer. Serta sumbangan pemikiran dan kegelisahan nasasumber dari Sekolah Pelita Netra di Makassar Sulawesi Selatan sehingga kami dapat menformulasikan produk sampai ke bentuk yang kongkrit.

\section{DAFTAR PUSTAKA}

Anonim, 2020. (http://studentsrepo.um.edu.my/ 7504/4/Tesisku.pdf) (akses 10 Agustus 2020)

Esdaniar Khoirunisa, Dwi Aries Himawanto. 2018 Perbandingan Ketersediaan Ubin Tekstur Pemandu Untuk Tunanetra di Tempat Umum antara Kota Surakarta dan Kota Nagoya. Jurnal Kajian Wilayah 9(1): 34-45

Permen PU Nomor 30 Tahun 2006 Tentang Pedoman Teknis Fasilitas dan Aksesibilitas Pada Bangunan Gedung dan Lingkungan.

Pramono, A. 2008. Pemodelan 3 Dimensi Notasi Laban dengan Direct Kinematic dan Matrik Transformasi. Jurnal Informatika 4(2): 175-190. 
Jurnal Perempuan dan Anak Indonesia

Syafi'ie, M. 2014. Pemenuhan Aksesibilitas Bagi Penyandang Disabilitas. Jurnal Inklusi 1(2): 269-308

Syaharuddin, A. 2017. Pakarena di Sulawesi Selatan: Dari tarian tradisional ke neotradisional. URL: http://studentsrepo. um.edu.my/7504/4/Tesisku.pdf. (akses 9 Desember 2019)

Undang-Undang Republik Indonesia Nomor 5 Tahun 2017 Tentang Pemajuan Kebudayaan.

Wawancara dengan Ewis Mulyasari (Siswi Pelita Netra) Kamis, 5 Desember 2019 di Pelita Netra Jalan Andi Djemma Lorong 2 No.1, Banta-Bantaeng, Kecamatan Rappocini Kota Makassar Sulawesi Selatan.

Wawancara dengan Scholastica Suryati Alus (Mahasisiwi UNM Psikologi 2019) pada Kamis, 5 Desember 2019 di Pelita Netra Jalan Andi Djemma Lorong 2 No.1, Banta-Bantaeng, Kecamatan Rappocini Kota Makassar Sulawesi Selatan. 